\title{
Move raises problems
}

\section{Munich}

THE uncertain life of the West Berlin Academy of Sciences, which must leave its present home by July next year, seems destined to continue. Criticism from the opposition Social Democrats (SPD) in the Land of Hesse may prevent the beleaguered academy from moving there, despite earlier indications that Hesse would be a safe haven. The SPD has set "high hurdles", according to a spokesman, before it will accept the academy.

The academy became a source of discord in Berlin politics after it was pushed through the parliament in 1987 by the conservative Christian Democratic Union (CDU; see Nature 329, 659; 1987). SPD and Green Party politicians, then in the opposition, criticized the academy as a "debating club" with conservative leanings. They vowed to shut the academy once they gained power and, in May this year, the now left-wing government of West Berlin proposed a law to do just that.

With the help of his conservative coalition partners, Hesse science minister Wolfgang Gerhardt (Free Democrat) responded to the Berlin decision in June by offering to "adopt" the academy, and to give it the same financial support as it had been receiving in West Berlin DM 8.5 million ( $\$ 4.6$ million) a year. This offer needs the approval of the Land parliament of Hesse: debate is about to resume, and a final vote is expected in December or January.

But now academy president Horst Albach has said that he will not accept the offer unless the SPD in Hesse also agrees to support the academy. Having already been the victim of a change of government, Albach wants to avoid further uncertainty over the future of the academy.

In response, the SPD in Hesse has demanded a role for political parties in the academy's board of directors as well as strong representation by the universities and research institutes of Hesse. "The academy will be a big financial burden for Hesse", said SPD spokesman Erich Stather. "It is only logical that we want a chance to express our views. What bothers us the most is having the academy floating free of all other scientific institutions." The SPD met in private this week to discuss its position on the academy.

Will the academy be able to accept the terms demanded in Hesse and still remain independent? Academy spokesman Eberhard Vogt calls the problem a case of "Scylla and Charybdis" - the academy is trapped between two hazardous alternatives. Some members of the governing board, which manages the day-to-day affairs of the academy, oppose an industry-financed future for the academy for fear of losing independence.

Nevertheless, the mood in the academy is optimistic. "We have been criticized by conservatives at the University of Frankfurt for being too left-wing, whereas leftwingers in Kassel have said we are too conservative", he said. "So we must be in just the right place politically now." Albach is grateful for the chance to correct the "birth defect" in the way the academy was voted into existence in West Berlin, and he has been crisscrossing Hesse in an attempt to generate support for the new version of the academy.

Ironically, if the academy were to accede to the demands of the SPD in Hesse, it would belatedly live up to the demands that the SPD in West Berlin proposed when its future was discussed in 1986-87. But this is no longer enough for the West Berlin Senate to invite the academy to stay: the Greens would oppose any such move as a violation of their coalition agreement with the SPD.

In a further irony, some activities of the West Berlin academy will probably be allowed to stay in the city if a compromise is reached in Hesse. Hesse is expected to approve the existence of such a "satellite academy" and there is even talk in the West Berlin SPD that some new academy projects would be welcome - a belated tribute to what some are calling the "academy in exile". Steven Dickman

\section{BRITISH UNIVERSITIES}

\section{United stand in move to greater efficiency}

\section{London}

FouR British universities have appointed a firm of management consultants to try to make them more efficient. In the first move of its kind in higher education, the Universities of Birmingham, Leicester, Loughborough and Warwick have joined forces to maximize their use of resources to offset tighter government budgeting.

The PA Consulting Group will carry out efficiency audits of services such as residences, libraries, maintenance and catering in the four universities.

For the next three years, PA will draw up comparative studies across the four universities and will also look at each area specifically.

Professor Gerald Bernbaum, executive pro-vice-chancellor and registrar of the University of Leicester, said the universities were simply following Universities Funding Council advice to carry out an audit. He said PA would help them "share good practices" and that he was confident the study, which was at a "reasonable cost", would pay for itself in time.

Ben Webb

\section{New minister, old problems \\ Cape Town}

IN a cabinet reshuffle last month, the new South African president, F.W. de Klerk, announced the return of Dr Gerrit Viljoen as Minister for National Education, with an additional appointment as Minister for Constitutional Development. Viljoen, a graduate of the Universities of Cambridge and Leiden, was professor of Greek at the University of the Witwatersrand in Johannesburg before entering politics, and had previously served as education minister from 1980 to 1984 . He was subsequently made Minister of Cooperation and Development, but a year later was effectively moved to the sidelines as Minister of (African) Education and Training, reputedly because he was not a member of exPresident Botha's inner circle. But he was one of de Klerk's staunchest supporters in deposing Botha, and has been rewarded with two of the most crucial portfolios in the new cabinet.

On top of his responsibility for overseeing constitutional reform, Viljoen is faced with the task of defusing the country's growing educational crisis. In 1986, the government declared a commitment to the elimination, over a 10-year period, of racial inequalities in primary and secondary education, but earlier this year was forced to abandon that policy as economically impossible. Education already accounts for 20 per cent of budget spending in South Africa, and in the current economic climate the increases that would be needed for large-scale educational reform are unlikely to materialize. And despite its goal of educational equality, the government is fiercely committed to the provision of separate educational facilities as it regards integration of schooling as an issue too sensitive for the white electorate to accept.

Yet there are signs that this same electorate may be ready to face up to the reality of the situation. The Johannesburg High School for Girls, threatened with closure due to dwindling numbers of white students in its catchment area (which has become a de facto mixed area in recent years) decided earlier this year to go private instead. The state has allowed integration in private schools for the past decade, and has also given them limited state subsidies without taking away their charitable status. By allowing a state school to become independent, the government can allow integration without taking overt responsibility.

Academics in South Africa are generally optimistic about Viljoen's appointment, because of his credentials and also because during his first period in the education office universities and museums were well-treated. But he now has more difficult tasks to deal with, and fewer resources to apply to them.

Michael Cherry 